\title{
EDITORIAL: Two decades of critical inquiry
}

$P$ ACIFIC JOURNALISM REVIEW is far more than a research journal. As an independent publication, it has given strong support to investigative journalism, socio-political journalism, political economy of the media, photojournalism and political cartooning in its two decades of publishing, which have all been strongly reflected in the character of the journal.

It has also been a champion of journalism practice-as-research methodologies and strategies, as reflected especially in its Frontline section, initiated by one of the co-editors of this volume, Wendy Bacon. Barry King and Philip Cass are also co-editors and have been key contributors at various stages. Many people have contributed to developing $P J R$ along the way.

First of all, I must acknowledge Australian Journalism Review which is almost double the age of $P J R$, because this is where I first got the inspiration in establishing the journal. While I was head of journalism at the University of Papua New Guinea in 1993 I was really frustrated at the lack of good Pacific-specific media and journalism literature and research to draw on as resources for both critical studies and practice-led education.

So I looked longingly at $A J R$, and also contributed to it. I also looked longingly at the London-based Index on Censorship as another publication to emulate. And I thought, Why not? We can do that in the Pacific and so I persuaded the University of Papua New Guinea Press to come on board and published the first edition at the derelict campus printer in Waigani in November 1994.

The actual birthday edition was last November with the "Failed states" and the environment' cover theme launched at the 20th anniversary conference 'Political journalism in the Asia-Pacific', hence the collection of papers in this edition largely drawn from that stimulating and inspirational event. A follow-up collection of PJR2014 conference papers devoted to independent documentary-making, including Jim Marbrook's compelling film Cap Bocage about nickel mining in New Caledonia, and unthemed articles will be published in the October edition this year.

AJR's founder John Henningham, Mark Pearson, Ian Richards and Martin Hadlow have all been journal mentors for me and my team and it is appropriate that Professor Ian Richards, editor of the $A J R$, spoke at the birthday celebration function and also paid tribute to the journal in a recent $A J R$ editorial:

Today, Pacific Journalism Review plays a vital role publishing research from and about this part of the world. This is important for a number of reasons, not least because most academics ground their work in situations with which they are most familiar, and this frequently produces articles which are extremely local. If 'local'

PACIFIC JOURNALISM REVIEW 21 (1) 20157 
means London or Paris or New York, then it's much easier to present your work as 'international' than if you live in Port Vila or Pago Pago, Auckland or Adelaide.

Over the two decades of its existence, $P J R$ has published papers relating not only to New Zealand, but also to Australia, as well as the huge area of the globe known as Oceania. In doing so, it has helped address the gross imbalance in academic publishing between the Global North and the Global South, and demonstrated the validity of journalism practice as a research methodology (Richards, 2015).

This has been a major factor in my 'dogged perseverance' over the years, as Ian Richards put it. I have had a strong desire to thrust aside the Antipodean academic cringe factor and sense of inferiority, which leads to some journalism programme leaders in New Zealand insisting on their colleagues publishing 'only in international journals', i.e. Global North publications. Since returning to New Zealand in 2002 to join AUT University, which has the largest (and arguably the most dynamic) School of Communication Studies in the country, I became committed to expanding the journal to cover New Zealand, Māori and Indigenous studies research as well as the Asia-Pacific region.

The New Zealand Journalism Review, published at the University of Canterbury, lasted just nine years (1988-97). There was a need for a journal to continue reflecting New Zealand journalism research. The success of PJR has also been founded on the quality of its Journalism Education and Research of Australia Association (JERAA) contributors and international board of advisers and researchers, and the wide range of international media and development research that has included, for example, a paper on 'Audiovisual cultural artifacts of protest in the Basque Country' in the last edition (Letamendia et al, 2014).

Two testaments to the contribution of PJR to scholarly journalism studies are published in this edition with Walter Fraser, head of AUT's Office of Pacific Advancement, saying the journal has 'positioned itself as a quality publication ... where those committed to the development and advancement of the Pacific island region can find a platform to debate Pacific media issues' and Lee Duffield who has prepared a comprehensive and rigorous analysis of two decades of research and publication (Duffield, 2015). As Fraser notes:

The political events in Fiji [since the first coup on 14 May 1987] ... have had a profound effect on political journalism in the Pacific. Many of my contemporaries who worked as journalists in Fiji at the time, paid dearly for defending the Fourth Estate. They were unified in their views and they vehemently defended the right to call things as they saw it - a spade was a spade, black was black and white was white. (Fraser, 2015)

The biggest inspiration I have had over many years is Professor Wendy Bacon, who has been a co-editor and been involved with many issues right back to the early days in Papua New Guinea. She has also been the driving force for the Frontline investigative

\section{PACIFIC JOURNALISM REVIEW 21(1) 2015}


journalism section, and arguing for wider academic recognition of journalism-as-practiceas a research methodology. She argues:

Our aim with Pacific Journalism Review is to demonstrate a developing relationship which includes the collaborative production of journalism itself, the provision of spaces for open and honest discussion which cut across organisational boundaries, the development of links between the production of journalism and the scholarly study of it, and mutual support in providing access to innovative thinkers and producers outside our region. (Bacon, 2012)

Monash University professor of journalism Chris Nash has also been a major contributor and co-editor. So too, have professor Mark Pearson of Griffith University and associate professor Trevor Cullen of Edith Cowan University.

After five years in Papua New Guinea (1994-8) and five years in Fiji (1998-2002), the journal relocated to AUT University where it has enjoyed a completely new lease of life with greater academic support resources over the past dozen years. However, PJR has retained University of the South Pacific links, with both Pat Craddock and Shailendra Singh being major contributors. At AUT, Professor Barry King was the critical supporter who got us reestablished with the first New Zealand-based edition themed on 'Iraq and the media war' in 2003 (PJR, 9, 2003). Alan Samson, Allison Oosterman, Susan O'Rourke and Evangelia Papoutsaki (and more recently Philip Cass from Unitec) have also contributed in editorial roles, such as reviews editor. King wrote in the 'rebirth' edition editorial:

If the fates recognise an obligation to attend a rebirth as much as a birth, then the publication of this issue is auspicious. Coming on the heels of the recent Pacific Islands Forum in Auckland, PJR can draw on a context in which issues of neocolonialism, Trans-Tasman hegemony, racism and ethnicity, most often agonised over in the confines of academia, have become the stuff of popular journalism and demagoguery ...

The journal's contribution to an emerging debate on the geopolitical future of the region will be to maintain an analytic momentum that surpasses what is fashionable, critically engaging with the political agendas that strive for the accolade of the leading idea, the transparent truth and the received wisdom. (King, 2003)

Behind the scenes at PJR, several people who are not on the editorial board or with editorial roles are acknowledged here. They include Tui O'Sullivan; school manager Kevin Upton, who keeps us afloat; faculty dean Professor Desna Jury and associate dean research Associate Professor Tony Clear; and the Pacific Media Centre advisory board team, especially Isabella Rasch and Dr Camille Nakhid.

However, the person I would like to acknowledge most is Del Abcede, who has worked tirelessly on the journal for much of the past decade as the designer, also organising the mail-outs, acting as chief photographer and unpaid organiser-and keeping me sane.

PACIFIC JOURNALISM REVIEW 21 (1) 20159 


\section{Pacific Journalism Review 20th Anniversary 2014}

Some editorial and production staff and contributors since 1994

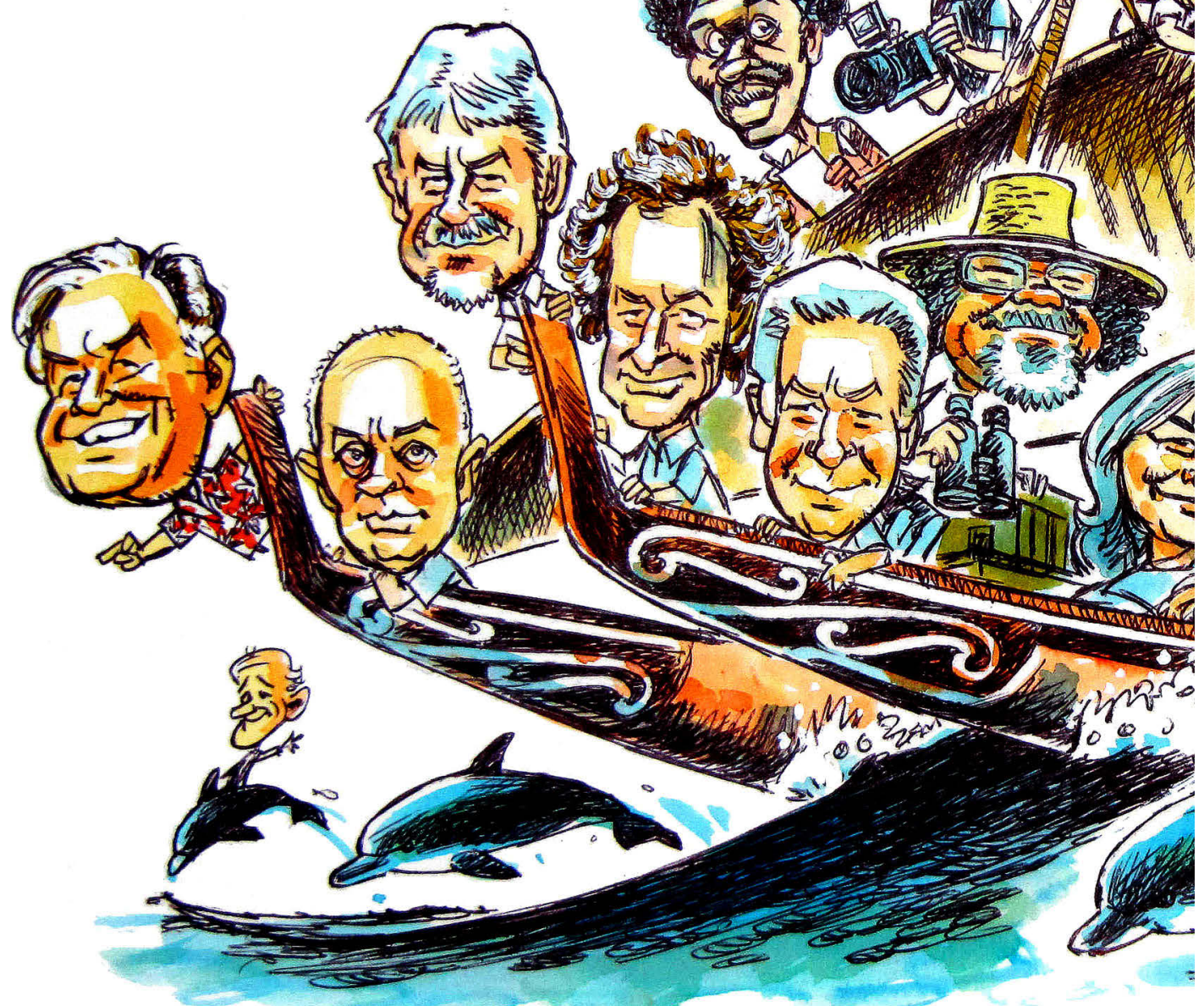

Figure 1: Key to the PJR cartoon: (From left): Pat Craddock (on the prow), Chris Nash, Mark top of the sail); Lee Duffield, Trevor Cullen, Philip Cass, Wendy Bacon, Tui O'Sullivan, Kevin Upton (pointing 'wrong way'). Barry King is on the water skis and cartoonist

Shai Malc 


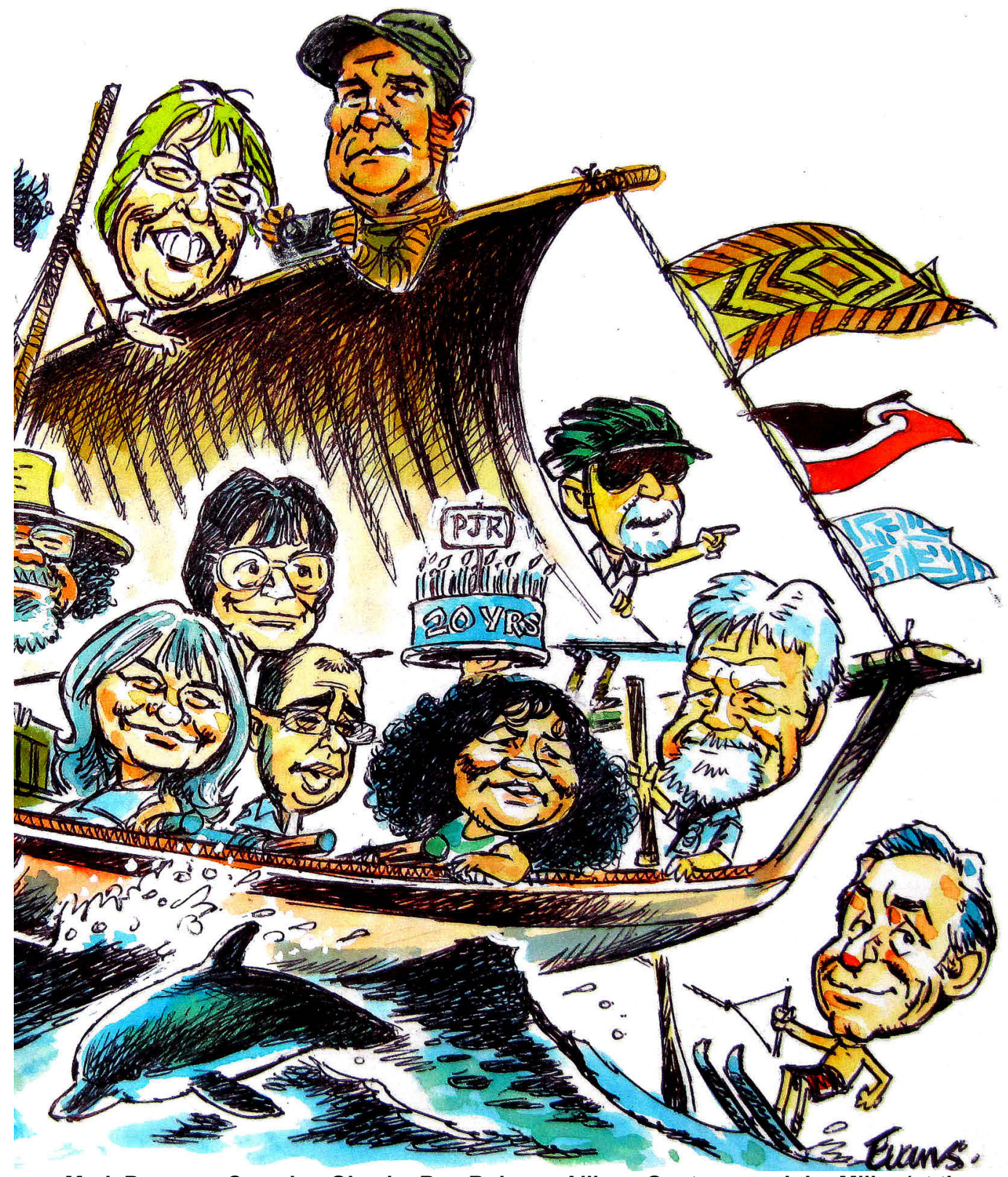

I, Mark Pearson, Campion Ohasio, Ben Bohane, Allison Oosterman, John Miller (at the ivan, Shailendra Singh, Del Abcede (with the birthday cake), David Robie (steering), and st Malcolm Evans is riding a dolphin. 
POLITICAL JOURNALISM IN THE ASIA-PACIFIC

In the very first edition of PJR in 1994, I wrote in the editorial:

There is surprisingly little reflective journalism or analysis of the state of the media today in the Pacific, or of issues such as freedom of information, freedom of expression, ethics, ownership ....

Pacific Journalism Review will combine the characteristics of an academic journal and a professional industry publication. It will include both research and articles of general interest by journalists and media people - anything that will enhance the quality of journalism and the study of it in the South Pacific will be considered for publication by the editorial board. (Robie, 1994)

Our first issue dealt with threats of secession from the state of Papua New Guinea by the Islands Region provinces - and censorship. Over the years, PJR authors and researchers have tackled the Sandline mercenary crisis and the Bougainville war in Papua New Guinea, four coups in Fiji, West Papuan repression, mining and resource extraction, environmental degradation, media history and now climate change.

Some of this story has been told in a Pacific Media Centre video available on YouTube, produced by Sasya Wreksono. I believe that in 20 years we have achieved precisely what we set out to do, being a critical conscience of Asia-Pacific socio-political and development dilemmas and look forward to the future challenges.

DOLITICAL journalism is a fitting theme for this special celebration edition with asylum-seeker Pacific 'anti-solutions' and Australian secrecy, climate change, military coups, martial law in the Philippines, political ecology in New Caledonia, gender politics, and human rights violations in Pakistan and West Papua all part of the mix. Five articles about Fiji reflect the dominance of eight years of post-coup politics leading to the restoration of a democracy of sorts in the September 2014 General Election. The first of these, by Repúblika founder and editor Ricardo Morris, sets the tone: 'If the media were subdued after the 2006 takeover and especially after the abrogation of the 1997 Constitution in 2009, it was truly intimidated when the Media Decree came into effect in 2010.' But Morris remains optimistic. Borrowing a Dickensian line, he says while Fiji Islanders may have been living through 'the worst of times', 'the best of times' are now on the horizon.

Two articles about Australia's worrying slide in the media freedom rankings, with collaborative examinations by Mark Pearson and Joseph Fernandez on censorship in Australia and the growing intrusions into free expression and 'shield' laws and the legal and ethical implications for journalists and their confidential sources, make up the next section in this book.

In 'Atolls in the ocean-canaries in the mine?', Chris Nash explores the state of climate change reporting on the Pacific in the Australian media with a case study contrasting the perspectives of two high profile journalists, while Arjun Rajkhowa offers

12 PACIFIC JOURNALISM REVIEW 21(1) 2015 
an essay contrasting the 'Team Australia' rhetoric of Prime Minister Tony Abbott with a multicultural vision.

The large Fiji section includes chapters on both macro political censorship and repression at a national level and micro papers revealing the depth of administration expediency and self-censorship at a journalism educational level. Mosmi Bhim, an early graduate of the USP regional journalism programme, writes about 'stifled aspirations' with the 2014 elections being held under restrictive laws, while Shailendra Singh studies the evolution of harsh media laws in Fiji and how they have impacted on journalism and society. Former acting University of the South Pacific journalism head Pat Craddock details a conflict between the journalism staff and the university administration over a media release criticising the new military chief, Brigadier-General Mosese Tikoitoga, for justifying torture he had admitted to carrying out in the 2006 coup (Marks, 2014). Many USP graduates over the years, including founding Wansolwara editor Stanley Simpson, have made important contributions to Fijian and Pacific journalism, and indeed to PJR itself, as with contributions by Mosmi Bhim, Reggie Dutt and Christine Gounder, for example. It is timely that Eliki Drugunalevu and Irene Manueli should plot the history of the award-winning student newspaper and the political challenges and gags faced in campus journalism.

In New Caledonia, Nicole Gooch argues for a 'multi-dimensional and nuanced journalism' investigation into the US\$6 billion nickel mine and smelter owned by the Brazilian transnational Vale at Goro. She suggests political ecology as the framework for this inquiry.

Giving examples of three Pakistani journalists who lost their lives after their investigations during America's so called 'War on Terror', Rukhsana Aslam offers an account of the nature of the dangers and threats that are faced by the journalists in Pakistan who report on armed political conflicts.

In the Philippines, Amy Forbes interviews and profiles courageous women journalists and their survival strategies during the Marcos Martial Law years, while Del Abcede and David Robie document the digital era 'e-Martial Law' and 'Magna Carta' developments: 'By entrenching criminal libel, and with the highest court arguing constitutional justification with higher penalties for online breaches, the Philippines has signalled it wants to impose a "chilling effect" on the nation's media.' Journalists are being killed with impunity in the Philippines with the world's worst massacre of news workers at Ampatuan, Mindanao, in 2009. Thirty-four media people were among the 58 gunned down in an ambush of a political motorcade and five years on there is still no justice.

Peace and West Papua affairs activist Maire Leadbeater traces the duplicity and betrayal by New Zealand diplomats during the transitional period when the Dutch colonial administration effectively surrendered power to the Indonesians under United Nations manipulation. 
POLITICAL JOURNALISM IN THE ASIA-PACIFIC

Finally, this edition of PJR concludes with the Frontline section. Journalism Research editor Kayt Davies documents and analyses the process of creating investigative journalism about an Indigenous-run legal bid in the Solomon Islands to challenge potentially corrupt logging approvals on the volcanic island of Kolombangara. The article is a revelation on the flawed and stereotypical reasoning used by some editors in making editorial decisions over complex Pacific stories. She concludes: 'This stereotyping is reinforced by the mainstream media's habit of giving preference to stories about uprisings and natural disasters that portray Pacific people as being in disarray, rather than empowered and competent.'

\section{References}

Duffield, L. (2015). Pacific Journalism Review: Twenty years on the frontline of regional identity and freedom. Pacific Journalism Review, 21(1), 14-29.

Fraser, W. (2015). A tribute to a commitment to the Pacific region. Pacific Journalism Review, 21(1), 11-13.

King, B. (2003). A timely alternative vision [Editorial]. Pacific Journalism Review, 9, 6-7.

Letamendia, A.; Del Amo, I. A.; and Diaux, J. (2014). Audiovisual cultural artifacts of protest in the Basque Country. Pacific Journalism Review, 20(2), 224-240.

Marks, K. (2014, June 20). Fiji military leader admits beatings, torture. The Age. Retrieved on March 24, 2015, from www.theage.com.au/world/fiji-military-leader-admits-beatings-torture20140620-zsg90.html

Pacific Journalism Review. (2003). Iraq and the media war: Lies spin and propaganda. v9.

Richards, I. (2015). Note from the editor [Editorial]. Australian Journalism Review, 26(2), 1.

Robie, D. (1994). Editorial. Pacific Journalism Review, 1, 4.

Wreksono, S. (2014). The life of Pacific Journalism Review [Short documentary]. Available at: www.youtube.com/watch?v=Brq_AgBS-ys

14 PACIFIC JOURNALISM REVIEW 21(1) 2015 